\title{
KONSEP INTERAKSI SOSIAL DALAM KOMUNIKASI, TEKNOLOGI, MASYARAKAT
}

\section{THE CONCEPT OF SOSIAL INTERACTION IN COMMUNICATION, TECHNOLOGY, COMMUNITY}

\author{
Angeline Xiao \\ Mahasiswa Magister Ilmu Komunikasi, Universitas Pelita Harapan, The Plaza Semanggi, \\ J1. Jenderal Sudirman No.50, RT1/RW4, Karet Semanggi, Kecamatan Setiabudi. Jakarta Selatan, DKI Jakarta, 12930. \\ Email: angelxiao@naver.com/ angelnatt@yahoo.com / angelnatt0407@gmail.com \\ Diterima : 9 Juni 2018| Direvisi : 27 Juni 2018| Disetujui : 9 Agustus 2018
}

\begin{abstract}
Sosial interaction is generally a requirement of every human being. Humans are sosial beings, therefore every human needs to have interact each other. So humans can survive. And as time goes by the level of needs for sosial interaction is increasing. And the media to have an interaction is increases even more too. Each person has his own motivation in sosial interaction. There are three main principles of an interaction, namely the meaning (meaning), language (language), and thoughts (thought). This study uses descriptive qualitative research methods. In the study it was found that, in getting to know or do sosial interaction there are still many people who are happy to do it directly or face to face. The use of sosial media is only an alternative addition, when they cannot reach their interlocutors directly.
\end{abstract}

Keywords: sosial interaction, , motivation, technology media

\begin{abstract}
Abstrak
Interaksi sosial pada umumnya merupakan kebutuhan setiap manusia. Setiap manusia merupakan mahluk sosial, maka dari itu setiap mereka membutuhkan interaksi dengan sesamanya. Sehingga manusia dapat bertahan hidup. Dan seiring dengan berjalannya waktu tingkat kebutuhan akan adanya interaksi sosial pun semakin meningkat. Dan media untuk berinteraksi pun semakin banyak. Masing-masing orang memiliki motivasinya sendiri dalam melakukan interaksi sosial. Menurut seorang ahli sosiologi Herbert Blumer ada tiga prinsip utama dari sebuah interaksi, yaitu tentang pemaknaan (meaning), bahasa (language), dan pikiran (thought). Penelitian ini menggunakan metode penelitian kualitatif deskriptif. Dalam penelitian ditemukan bahwa, dalam berkenalan atau melakukan interaksi sosial masih banyak orang yang senang untuk melakukannya secara langsung atau face to face. Penggunaan sosial media hanyalah sebagai tambahan alternatif, ketika mereka tidak dapat menjangkau lawan bicaranya secara langsung.
\end{abstract}

Kata Kunci : Interaksi sosial , motivasi, media, teknologi

\section{PENDAHULUAN}

Bentuk umum dari sebuah proses sosial adalah interaksi sosial, dan arena bentuk-bentuk lain dari proses sosial hanyalah sebuah bentuk-bentuk khusus dari sebuah interaksi. Dengan begitu yang dapat disebut proses sosial, hanyalah interaksi sosial itu sendiri. Interaksi sosial adalah kunci dari semua kehidupan sosial, tanpa adanya interaksi sosial tidak akan mungkin ada kehidupan secara Bersama-sama. Syarat utama dari adanya atau hadirnya aktivitas-aktivitas sosial adalah adanya interaksi sosial (Wulandari).

Interaksi sosial sendiri merupakan hubungan yang dinamis, dimana hubungan tersebut berkaitan dengan hubungan antar perseorangan, antara kelompok satu dengan kelompok yang lainnya, maupun hubungan antara perseorangan dengan kelompok. Tidak jarang disebutkan bahwa seseorang akan menjadi sulit untuk bertahan hidup, apabila ia tidak menjalin interaksi dengan seorang individu lainnya. Hal ini merupakan dasar dari terjadinya proses sosial, yaitu interaksi sosial. Sosiologi sendiri merupakan ilmu yang mempelajari tentang fenomena sosial di masyarakat. (sosiologis.com, 2017)

Seorang sosiolog ternama dari Kanada, Erving Goffman berpendapat, bahwa masyarakat pun terbentuk karena adanya interaksi diantara anggotanya. Karena tanpa adanya interaksi makan akan sulit memahami dunia sosial. Pada titik ini, interaksi adalah tindakan yang terletak pada tataran praktis, bukan sekadar teoritis. (sosiologis.com, 2017)

Bila pada zaman dahulu manusia masih menggunakan surat yang dikirimkan merpati, 
kemudian berkembang ke kantor pos, namun kondisi seperti itu masih tetap membutuhkan waktu beberapa hari, hingga pesan itu dapat sampai ke tangan penerima pesan. Kini manusia tidak lagi memerlukan banyak waktu bila ingin mengirimkan pesan. Mereka bisa menggunakan sms, ataupun chatting kepada lawan bicaranya, atau si penerima pesan. Dengan hadirnya teknologi saat ini manusia tidak lagi memerlukan waktu yang panjang ketika ingin bertukar pesan. Pola komunikasi manusia saat ini tentu berubah. Adanya teknologi di dalam kehidupan manusia, menjadikan pola komunikasi lebih maju, dan teknologi telah mengubah bentuk dan pola komunikasi tersebut.

Pengguna teknologi terutama aplikasi chatting, semakin meningkat setiap tahunnya. Menurut laporan dari Tech In Asia, pada Januari 2017, sebanyak 46130 juta pengguna aktif mobile applications di Indonesia. Dapat terlihat bila saat ini pengguna teknologi berbasis internet sangatlah banyak di Indonesia. Setiap harinya semua orang menggunakan aplikasi chatting untuk bertukar pesan singkat, dan menggunakan email untuk bertukar pesan yang sifatnya lebih formal dan penting, atau berisikan data yang berat. ( Pratama, 2017)

Selain itu bila pada dahulu kala untuk berkenalan dengan orang-orang baru, kita masih harus berusaha mendekati orangnya secara langsung, menyapa orang tersebut secara langsung. Sehingga orang tersebut akan melihat kearah kita dan mulai memberikan feedback. Namun dengan hadirnya teknologi, kini kita tidak perlu menyapa orang lain yang asing secara langsung, bahkan untuk menemukan orang-orang asing untuk berkenalan. Karena dengan kemajuan teknologi saat ini, manusia hanya perlu mendownload aplikasi yang disediakan oleh para developer atau pengembang aplikasi. Banyak aplikasi-aplikasi di handphone yang dipakai saat ini, sehingga pilihan saat ini tidak hanya satu tapi banyak. Contohnya adalah pengguna Tinder.

Melalui Tinder seseorang akan sangat mungkin bertemu dengan lawan bicaranya secara random. Tinder disini akan memilihkan kita orang-orang yang besar kemungkinan akan kita pilih atau ajak untuk berinteraksi. Di Tinder ada piliha swipe right dan swipe left. Dimana swipe left diperuntukan untuk user yang tidak ingin memilih orang yang muncul di window, dan swipe right sendiri diperuntungkan untuk user yang ingin mengajak user yang ada pada windownya berinteraksi. Dan keduanya akan dinyatakan match, apabila dua orang tersebut saling memberikan swipe right. Dari hal ini terlihat jelas bahwa ketika interaksi sosial akan di mulai ketika kedua orang yang bersangkutan sedang berusaha untuk saling menyesuaikan diri satu sama lain.

Hadirnya teknologi apakah benar-benar mengubah pola interaksi sosial manusia ? Dari interaksi sosial yang konvensional harus bertatap muka, menjadi interaksi sosial yang hanya bermodalkan internet dan beberapa aplikasi chatting. Tujuan dari penelitian ini adalah untuk mengetahui hadirnya teknologi yang mampu mengubah pola interaksi manusia dan alasan di balik penggunaan teknologi dalam proses interaksi sosial.

Dan peneliti berharap penelitian ini dapat berguna sebagai acuan bagi para peneliti lainnya dalam membuat, mengupas ataupun menjadi pembanding bagi penelitian mengenai interaksi sosial lainnya.

\section{METODE}

Dalam penelitian ini, pendekatan yang digunakan adalah interaksionisme simbolik, dimana setiap individu yang melakukan interaksi tentunya memiliki makna dibalik aktivitas tersebut. Herbert Blumer dan George Herbert Mead merupakan orang-orang pertama yang mendefinisikan teori interaksionisme simbolik. Blumer mengemukakakn tiga prinsip utama interaksionisme simbolik, yaitu tentang pemaknaan (meaning), bahasa (language), dan pikiran (thought). Prinsip utama ini nantinya akan mengarah kepada konsep "diri" seseorang dan sosialisasinya kepada "komunitas" yang lebih besar, masyarakat (Griffin, 2003)

Blumer mengajukan prinsip pertama bahwa human act toward people or things on the basis of the meanings they assign to those people or things. Manusia berbuat atau berperilaku terhadap manusia yang lainnya biasanya dilandasi atas sebuah pemaknaan yang mereka sendiri dipakaikan kepada pihak lain tersebut.

Prinsip kedua yang Blumer ungkapkan adalah meaning arises out of the sosial interaction that people have with each other. Sebuah makna akan muncul dari interaksi sosial yang bertukar secara alamiah diantara kedua orang yang sedang saling berinteraksi.. Sebuah makna bukanlah muncul ataupun terikat pada sesuatu atau sebuah objek secara alamiah. Makna tidak dapat muncul sendiri. Makna datang dari hasil proses negosiasi , menggunakan bahasa bahasa (language) dalam 
perspektif interaksionisme simbolik. Interaksi sosial tentunya akan menghasilkan makna yang beragam. Dan makna-makna itu sendiri tercipta bedasarkan sudut pandang masing-masing orang yang menerima dan memaknai interaksi itu sendiri.

Prinsip Blumer yang ketiga adalah "an individual's interpretation of symbols is modified by his or her own thought process" Interaksionisme simbolik menggambarkan proses berpikir sebagai perbincangan dengan diri sendiri. Dan proses berbincang dengan diri sendiri itu sifatnya refleksif. Namun Mead memiliki pemikiran lain, ia berpendapat bahwa, sebelum manusia bisa berpikir, manusia membutuhkan bahasa (Griffin, 2003).

Jika kita ingin memahami seorang pelaku, maka kita semestinya men-dasarkan pemahaman itu pada apa yang mereka lakukan. Tiga hal yang sangat penting mengenai konstruksi teori Interaksi Simbolik, adalah (1) Fokus pada interaksi antara pelaku dan dunia; (2) Pandangan bahwa baik pelaku maupun dunia sebagai proses yang dinamis dan bukanlah struktur yang statis; dan (3) Nilai yang dilekatkan pada kemampuan pelaku untuk menginterpretasikan dunia atau masyarakat sosial(Ahmadi , 2005).

Norman Denzin (1987) dalam Dadi pun berpendapat bahwa proses transformasi identitas dalam pendekatan teori interaksi simbolik, bertumpu pada upaya membangun konsep diri dan relasi-relasi sosialnya. Menurut Denzin, transformasi identitas adalah proses di mana seseorang secara aktif memeroleh citra diri yang baru, bahasa diri yang baru, hubungan-hubungan baru, dengan orang lain, dan ikatan-ikatan baru dengan tatanan sosial. Hal lain yang dijelaskan Denzin, individuindividu yang terlibat dalam interaksi tersebut tidak selamanya berjalan mulus, meski berasal dari budaya yang sama, karena menggunakan simbol yang tidak signifikan, simbol yang tidak bermakna bagi pihak lain. Akibatnya, orang tersebut harus terus menerus mencocokkan makna dan merencanakan cara tindakan mereka. Jika dikaitkan dengan metodologi, maka seperti yang telah disinggung sebelumnya, interaksi simbolik termasuk salah satu dari sejumlah tradisi penelitian kualitatif yang berasumsi bahwa penelitian sistematik harus dilakukan dalam suatu lingkungan yang alamiah, atau lingkungan yang artifisial seperti eksperimen (Ahmadi , Interaksi Simbolik: Suatu Pengantar, 2005)

Interaksi simbolik ada karena ide-ide dasar dalam membentuk makna yang berasal dari pikiran manusia (Mind) mengenai diri (Self), dan hubungannya di tengah interaksi sosial, dan bertujuan akhir untuk memediasi, serta menginterpretasi makna di tengah masyarakat (Society) dimana individu tersebut menetap. Seperti yang dicatat oleh Douglas (1970) dalam Ardianto (2007: 136), makna itu berasal dari interaksi, dan tidak ada cara lain untuk membentuk makna, selain dengan membangun hubungan dengan individu lain melalui interaksi.

Tak hanya melihat kepada pemikiran Blumer, namun merujuk juga kepada pemikiran Joseph Walther. Dalam Griffin (8th edition) Walther mengungkapkan pemikiran CMC Versus Face to Face : A Sip Instead Of a Gulp. Dimana pemikiran itu mengemukakan cara kita mengenal seseorang, apakah mengenalnya secara perlahan melalui sosial media $(\mathrm{CMC}=$ Sip $)$ atau mengenalnya secara langsung atau face to face (a gulp). Hadirnya media-media baru dalam memenuhi kebutuhan interaksi sosial, memberikan kita pilihan, dengan apa kita mau berinteraksi dengan orang-orang disekitar kita ? Dan bagaimana kita mau mengenal mereka, apakah mau mengenalnya secara langsung atau perlahan-lahan mencari tahu dan mengenalnya melalui media sosial.

Di dalam media sosial pengguna dapat mengatur dirinya, mengkontrol semua tentang dirinya, sendiri. Sehingga yang terlihat adalah idelanya diri orang tersebut, berbeda ketika kita bertemu langsung dan mengenal secara langsung. Joe Walther menamai teorinya dengan sosial information processing(SIP) karena ia yakin hubungan berkembang pada pihak-pihak yang awalnya ingin mendapatkan informasimengenai orang lain dan menggunakan informasi untuk membentuk kesan interpersonaltentang siapa mereka.Impression formationadalah gabungan gambaran mental seseorang yang dibentukorang lain.Walther menyorot dua ciri CMC yang menyediakan kerasionalan terhadap teori SIP: 1.Verbal cues. Pengguna CMC dapat membentuk kesan penuh dari orang lainberdasarkan konten linguistik dalam pesan online 2. Extended time. Pertukaran informasi sosial melalui teks CMC lebih 
lambat dari pada face-to-face sehingga dapat mengurangi tingkat pembentukan kesan. Lama penggunaan waktu diyakini memengaruhi hubungan CMC untuk menentukanapakah hubungan bisa mencapai tingkat keintiman yang diinginkan. Walther mengklaim bahwa keinginan manusia untuk affiliasi ketika orang-orang berkomunikasi online sama seperti komunikasi face-to-face. Tetapi karena CMC menghilangkan isyarat pesan, pengguna CMC hanya mengandalkan pesan verbal untuk menyampaikan informasi sosial yang sama. Dia meyakinkan bahwa pesan verbal nonverbal dapat digunakan secara bergantian. Walther menjelaskan bahwa sebelumkomunikasi elektronik, orang-orang mengembangkan hubungan pen-pal dengan mencari kesamaan dan mengekspresikan kasih sayang melalui tulisan katakata. Hubungan yang terjadi bisa menjadi loveletters, dan perkembangan hubungan yang sama juga dapat melalui CMC. Itu menunjukkan bahwa sejarah mendukung klaim SIP bahwa orang-orang secara kreatif mengadaptasi komunikasi mereka untuk menghubungkan batasan media.

\section{Teknik Pengumpulan Data}

Dalam penelitian ini, teknik pengumpulan data menggunakan sistem observasi. Dimana penulis menanyakan kepada responden secara random. Mengenai penggunaan sosial media atau face two face dalam berkenalan. Kemudian penulis juga menggunakan teknik observasi. Ketika menggunakan teknik observasi, peneliti harus dapat memusatkan perhatiannya. Karena peneliti akan mengamati secara menyeluruh mengenai apa yang di observasi. Pada permulaan observasi peneliti mengamati secara menyeluruh dan dengan ruang lingkup yang luas, kemudian memusatkan diri pada hal-hal yang menjadi fokus penelitianya dan akhirnya memilih hal-hal yang khas dan yang paling relevan untuk diamati dengan lebih cermat. Hal ini seperti yang dikemukakan Spradley ketika mengungkapkan bahwa tahapan observasi ada tiga yaitu; (1) observasi deskriptif, di mana peneliti mengamati semua yang ada secara menyeluruh, mendeskripsikan semua yang diamati, observasi ini disebut juga sebagai grand tour observation; (2) observasi terfokus, di mana pengamatan difokuskan pada aspek tertentu yang menjadi fokus penelitian, observasi ini disebut juga sebagai mini tour observation. dan; (3) observasi terseleksi, di mana peneliti menyeleksi fokus yang ditemukan secara lebih rinci lagi (James.P., 1980)
Kemudian, penulis juga memperkuat pendapat hasil observasi dengan melakukan wawancara. Sehingga hasil observasi lebih kuat. Depth Interview atau wawancara mendalam, yaitu suatu kegiatan yang dilakukan untuk mendapatkan informasi secara langsung dengan mengajukan pertanyaan antara pewawancara dengan yang diwawancarai. Bahkan keduanya dapat dilakukan bersamaan, di mana wawancara dapat digunakan untuk menggali lebih dalam lagi data yang didapat dari observasi. Seperti yang dikemukakan Sugiyono yang mengatakan bahwa dalam penelitian kualitatif, sering menggabungkan teknik observasi partisipatif dengan wawancara mendalam. Selama melakukan observasi, peneliti juga melakukan wawancara kepada orang-orang yang ada di dalamnya (Sugiyono, 2006)

\section{PEMBAHASAN DAN HASIL}

Bila sebelumnya sempat terpikirkan bahwa teknologi mengubah pola interaksi orang-orang, terutama ketika berkenalan. Maka dari hasil pembahasan ini kiranya kita dapat melihat hal yang berbeda lagi. Peneliti melakukan observasi dengan cara membandingkan penggunaan aplikasi chatting dan face to face atau in direct ketika memulai untuk berkenalan. Peneliti juga melihat beberapa responden terpilih dan meminta mereka untuk memilih dengan cara apa mau berkenalan, kemudian meminta mereka untuk cross, bertukar lagi cara kenalannya

Anastasia, dia memilih untuk berkenalan dan berinteraksi secara face to face atau in direct dari pada berkenalan dan berinteraksi menggunakan aplikasi. Karena menurut Anastasia ketika mereka bertemu secara langsung, ia bisa langsung melihat wajah asli dari orang yang ia ajak berkenalan, dan bisa lebih kenal sifatnya, meskipun hanya sedikit, namun dia masih bisa melihat mata dari orang yang ia ajak berkenalan. Karena ketika berkenalan atau bahkan melakukan interaksi, orang bisa saja kerap melakukan kebohongan, sehingga perlu untuk melihat wajahnya langsung terutama matanya. Dan ketika Anastasia di minta untuk berkenalan menggunakan aplikasi chatting, ia justru merasa tidak terlalu tertarik dengan perkenalan menggunakan aplikasi chatting tersebut karena menggunakan aplikasi chatting, ia tidak bisa melihat wajah dari orang yang ia ajak untuk kenalan, ditambah lagi, ketika menggunakan aplikasi, rawan terjadinya kejahatan. Bisa saja yang diajak berkenalan tidak benar-benar jujur, dan 
sebagai wanita, Anastasia merasa itu tidak aman. Sedangkan untuk interaksi sosial sendiri, bila interaksi itu terjadi dengan orang yang di kenal, menggunakan aplikasi chatting tidak terlalu menjadi masalah. Walaupun ada sedikit masalah, terkadang seperti salah paham, karena saat chatting kita tidak mengetahui apakah itu sedang bicara dengan nada tinggi atau tidak. Dan itu kadang menyebabkan seseorang menjadi salah paham. Sehingga menurut Anastasia, aplikasi chating terkadang tidak terlalu efektif, dan in direct masih menjadi pilihan yang lebih tepat untuk berinteraksi.

Selain Anastasia penulis juga mewawancarai salah satu mahasiswa di Jakarta, Michael. Bagi Michael, tidak menjadi masalah apabila berkenalan menggunakan aplikasi sejenis Tinder. Michael sudah menggunakan Tinder untuk berkenalan, dan bagi Michael, itu cukup memudahkannya untuk mendapat kenalan dan pertemanannya pun menjadi luas. Karena melalui Tinder ia dapat menemui banyak orang tanpa batas. Dan apabila ia tidak benar-benar tertarik, melalui Tinder, ia dapat menghindari orang tersebut. Beda dengan berkenalan secara langsung, dimana sekali lihat dan mau kenalan, ya tinggal kenalan tapi apabila tidak ingin melanjutkan perkenalan, ia tidak bisa menolak, ia harus menjauh perlahan, dan itu kadang merupakan suatu hal yang mengganggu

Tetapi tidak menutup kemungkinan juga bagi Michael untuk berkenalan melalui sistem in direct, karena terkadang berkenalan in direct cukup menyenangkan, karena dapat melihat lawan yang diajak kenalan secara langsung. Tidak terlalu menjadi masalah apabila orang yang dituju sudah sesuai dengan apa yang menjadi ekspetasinya Michael. Dan untuk interaksi sosial, Michael pun melihat keadaan terlebih dahulu. Apakah kondisinya bisa melalui aplikasi atau tidak. Karena apabila kondisi sedang tidak memungkinkan, maka tidak bisa pakai aplikasi, karena dapat menyebabkan distorsi.

Responden berikutnya adalah Windy, yang merupakan seorang karyawan . Untuk berkenalan Windy pun menghindari untuk berkenalan melalui Tinder. Karena kenalan dari Tinder tidak benarbenar menyenangkan seperti kenalan secara langsung. Kalau melalui Tinder, pertama kenalan hanya liat wajah saja, tanpa benar-benar merasa nyambung dan nyaman atau tidak saat berbincang. Tapi kalau kenalan secara langsung, kita bisa merasakan nyaman atau tidak bincang dengan orang tersebut, nyambung atau tidak berbincang dengan dia. Dan lebih enak kenalan dengn orang-orang secara langsung di tempat kerja, atau komunitas. Karena sebelum kenal lebih dalam kita sudah banyak lihat sehari-hari dia.

\section{KESIMPULAN}

Dari penelitian yang telah dilakukan, penulis menemukan fakta bahwa dengan hadirnya teknologi, kiranya hal tersebut tidak sepenuhnya mengubah pola komunikasi orang-orang. Sekalipun dalam berkenalan, orang-orang yang ingin berkenalan rata-rata tetap menyukai metode kenalan konvensional, dimana dalam berkenalan mereka akan bertatap muka langsung. Mereka akan bertemu langsung (in direct) dan saling berkenalan. Itu lebih menarik dan menyenangkan, sedangkan melalui aplikasi, biasanya mereka tidak benar-benar merasa nyaman, karena saat awal berkenalan mereka tidak saling bertemu. Dan untuk berinteraksi selanjutnya, kehadiran teknologi memang membantu, hanya saja tidak selalu bisa menggunakan teknologi seperti aplikasi chatting saat ingin bicara. Penggunaan teknologi ini masih harus melihat situasi dan kondisi di saat jam tersebut, karena terkadang ada situasi yang tidak memungkinkan untuk berintraksi menggunakan aplikasi, melainkan harus berbicara secara langsung / in direct.

Dari kesimpulan tersebut dapat dikatakan bahwa hadirnya teknologi tidak sepenuhnya mengubah pola interaksi manusia. Manusia yang berinteraksi masih tetap mempertimbangkan komunikasi secara langsung.

\section{DAFTAR PUSTAKA}

Ahmadi , D. (2005). Interaksi Simbolik: Suatu Pengantar. Interaksi Simbolik: Suatu Pengantar, 304-305.

Ahmadi, D. (2005). Interaksi Simbolik: Suatu Pengantar. Interaksi Simbolik: Suatu Penganta, 308-309.

Mead, G. (1934). Mind, Self and Society. Chicago: The University of Chicago Press.

Pratama, A. H. (2017, January 30). Perkembangan Pengguna Internet di Indonesia Tahun 2016 Terbesar di Dunia. Retrieved from Tech in Asia.com: https://id.techinasia.com/pertumbuhanpengguna-internet-di-indonesia-tahun-2016

Griffin, E. A. (2003). A First Look at Communication Theory, 5th edition. New York City: McGraw-Hill. 
Griffin, E. A. (2012). A First Look at Communication Theory, 8th edition. New York City: McGraw-Hill.

James.P., S. (1980). The Ethnographic Interview. New York City: Holt Renehart and Winston.

sosiologis.com. (2017, Deember 6). Interaksi Sosial: Pengertian dan Contohnya. Retrieved from sosiologis.com: http://sosiologis.com/interaksi-sosial

Sugiyono. (2006). Metode Penelitian Pendidikan, Pendekatan Kuantitatif, Kualitatif. Bandung : Penerbit Alfabeta.

Wulandari, T. A. (n.d.). Materi Pengantar Sosiologi, onesearch.id. 